\title{
HUBUNGAN STATUS EKONOMI KELUARGA DENGAN STATUS GIZI BALITA di POSYANDU V DESA KLETEK WILAYAH KERJA PUSKESMAS TAMAN SIDOARJO
}

\author{
Beatric Maria Dwi Jayanti Baga \\ e-mail: beatricbaga@gmail.com
}

\begin{abstract}
ABSTRAK
Terjadinya peningkatan Sumber Daya Manusia yang berkualitas merupakan tujuan utama dari pembangunan nasional. Peningkatan SDM didapatkan dari jumlah kelahiran bayi. kematian bayi dan balita. Akan tetapi, berdasarkan data dari WHO didapatkan sebanyak 54\% terjadi kematian pada bayi dan balita akibat status gizi yang buruk. Banyak faktor yang berhubungan dengan status gizi bayi maupun balita salah satunya adalah status ekonomi keluarga. Di Indonesia faktor ekonomi sangat berperan mengingat krisis ekonomi yang dialami sejak tahun 1997. Tujuan penelitian untuk mengetahui hubungan status ekonomi keluarga dengan status gizi balita di Posyandu V Desa Kletek Wilayah Kerja Puskesmas Taman Sidoarjo. Kuantitatif, desain analitik survei dengan pendekatan cross sectional. Variabel independen status ekonomi keluarga, variabel dependen status gizi balita. Populasi 115 ibu balita, sampel 90 ibu balita, teknik sampling aksidental, instrumen penelitian kuesioner, analisis data uji korelasi rank spearman, $\alpha=0,05$. Sebagian besar $(73,3 \%)$ status gizi balita tergolong baik. Status ekonomi keluarga ibu balita hampir setengah $(42,2 \%)$ tergolong kaya. Ibu balita hampir setengah $(40 \%)$ bekerja sebagai buruh/ pegawai tidak tetap. Ibu balita hampir setengah $(38,9 \%)$ berpendidikan SMA. Hasil uji korelasi rank spearman, $\rho(0,000) \leq$ $\alpha$. Adanya hubungan sedang antara status ekonomi keluarga dengan status gizi balita di Posyandu V Desa Kletek Wilayah Kerja Puskesmas Taman Sidoarjo membuat petugas kesehatan khususnya bidan setempat diharapkan lebih sering (6 bulan sekali) melakukan penyuluhan tentang gizi seimbang pada balita dan memberikan contoh menu seimbang dari bahan makanan yang murah, tapi mengandung gizi yang cukup.
\end{abstract}

Kata Kunci : Ekonomi, Keluarga, Gizi Balita

\begin{abstract}
The increase in quality human resources is the main goal of national development. HR increase is obtained from the number of births of babies. infant and toddler deaths. However, based on WHO data, $54 \%$ of deaths occur in infants and toddlers due to poor nutritional status. Many factors related to the nutritional status of infants and toddlers, one of which is family economic status. In Indonesia, economic factors play a significant role considering the economic crisis experienced since 1997. The aim of the study was to determine the relationship between family economic status and nutritional status of children in Posyandu V Kletek Village, Puskesmas Taman Sidoarjo Working Area. Quantitative, analytical survey design with cross sectional approach. Independent variable family economic status, dependent variable nutritional status of children. The population of 115 mothers of toddlers, samples of 90 mothers of children under five, accidental sampling techniques, questionnaire research instruments, analysis of spearman rank correlation test data, $\alpha$ $=0.05 .(0,000) \leq \alpha . \rho$ Most $(73.3 \%)$ nutritional status of children under five is classified as good. Nearly half (42.2\%) family economic status of under-five mothers is classified as rich. Almost half (40\%) mothers work as temporary workers / employees. Nearly half (38.9\%) mothers have high school education. Spearman rank correlation test results, The existence of a moderate relationship between family economic status and nutritional status of children in Posyandu V Kletek Village Taman Sidoarjo Health Center Work Area makes health workers, especially local midwives, expected more often (6 months) to conduct balanced nutrition information for toddlers and provide examples of balanced food items which is cheap, but contains enough nutrients.
\end{abstract}

Keywords: Economy, Family, Toddler Nutrition 


\section{PENDAHULUAN}

Krisis yang melanda perekonomian Indonesia pada pertengahan tahun 1997 telah berpengaruh negatif terhadap kondisi perekonomian secara menyeluruh dan khususnya terhadap kesejahteraan penduduk. Keadaan ini membuat sebagian masyarakat tidak mampu untuk mengakses pangan sehingga pada akhirnya berdampak pada keadaan gizi terutama anak balita, ibu hamil dan ibu menyusui. Kenaikan harga bahan pangan yang disertai dengan adanya kenaikan pendapatan akibat dampak dari krisis moneter yang berkepanjangan sejak tahun 1997 membuat masyarakat sulit untuk memenuhi standar gizi untuk anaknya.

Sebagian besar penduduk Indonesia pada saat ini, mengalami suatu kondisi yang dapat dikatakan tidak sakit akan tetapi disaat yang sama juga dapat dikatakan juga tidak sehat, dan umumnya disebut dengan kekurangan gizi. Keadaan kurang gizi seringkali terluputkan dari pengamatan masyarakat, akan tetapi secara bertahap membuat dampak terhadap tingginya angka kematian pada bayi dan balita, serta rendahnya umur harapan hidup. Data dari UNICEF (2010) menunjukkan bahwa sekitar 10-12 juta (50-69,7\%) anak balita di Indonesia berstatus gizi sangat buruk dan mengakibatkan kematian dengan 4 juta diantaranya berusia dibawah satu tahun.

Seluruh anak di Indonesia yang berusia 4-24 bulan (4,9 juta) sekitar seperempat jumlahnya, saat ini dalam kondisi status gizi kurang. Status gizi pada balita disebabkan oleh berbagai macam faktor yang disebabkan secara langsung dan tidak langsung. Penyebab langsung bisa disebabkan oleh makanan dan penyakit infeksi, sedangkan penyebab tidak langsung disebabkan oleh ketahanan pangan di keluarga, pola pengasuhan anak, pelayanan kesehatan dasar, kesehatan lingkungan dan penyebab mendasar masalah diatas adalah krisis ekonomi yang mempengaruhi ketidakseimbangan antara asupan makanan yang dikonsumsi serta adanya penyakit infeksi, yang akhirnya dapat berpengaruh pada status gizi balita.

Dari data yang diperoleh dari beberapa posyandu di Desa Kletek pada bulan Januari 2018 terdapat 534 balita. Dari 534 balita, di Posyandu V terdapat 115 balita dan yang mengalami status gizi kurang sebanyak 17 balita (14,7\%). Berdasarkan data diatas, penulis berminat untuk melakukan penelitian tentang "Hubungan Status Ekonomi Keluarga Terhadap Status Gizi Balita di Posyandu V Desa Kletek Wilayah Kerja Puskesmas Taman Sidoarjo".

\section{METODE}

Penelitian kuantitatif dengan analitik survei ini dilaksanakan pada bulan Mei - Juli 2018 dengan sampel sebanyak 90 baita dari total populasi 115 balita yang berkunjung di Posyandu V Desa Kletek Wilayah Kerja Puskesmas Taman Sidoarjo. Teknik sampling menggunakan sampling aksidental.

Variabel penelitian adalah status ekonomi keluarga dan status gizi balita. Data dikumpulkan dengan menggunakan alat ukur kuesioner berupa pertanyaan yang ditanyakan langsung dan langsung dijawab oleh responden yakni ibu balita yang berkunjung di Posyandu V Desa Kletek. Selanjutnya data dianalisis dengan uji Rank Spearman $(\rho=0,05)$.

\section{HASIL PENELITIAN}

Wilayah penelitian Posyandu V Desa Kletek secara geografis terletak di Kelurahan Kletek dan Kecamatan Taman, yang berbatasan dengan Kelurahan Geluran, Kalijaten, Ngelom, dan Wonocolo.

\section{Usia Ibu Balita}

Tabel 1 Frekuensi Usia Ibu Balita di Posyandu V Desa Kletek, Mei 2018

\begin{tabular}{lcc}
\hline \multicolumn{1}{c}{ Usia } & $\mathrm{f}$ & $\%$ \\
\hline$<20$ tahun & 6 & 6,7 \\
20-30 tahun & 45 & 50 \\
$>30$ tahun & 39 & 43,4 \\
Jumlah & 90 & 100 \\
\hline
\end{tabular}

Tabel 1 dapat dilihat bahwa mayoritas usia ibu balita berusia 20-30 tahun sebanyak $45(50 \%)$ ibu.

Usia Balita

Tabel 2 Frekuensi Usia Balita di Posyandu V Desa Kletek, Mei 2018

\begin{tabular}{lcc}
\hline \multicolumn{1}{c}{ Usia } & $\mathrm{f}$ & $\%$ \\
\hline $0-12$ bulan & 28 & 31,1 \\
13-24 bulan & 16 & 17,8 \\
24-36 bulan & 21 & 23,3 \\
37-60 bulan & 23 & 27,8 \\
Jumlah & 90 & 100 \\
\hline
\end{tabular}


Tabel 2 dapat dilihat bahwa mayoritas usia balita berusia 0-12 bulan sebanyak 28 $(31,1 \%)$ balita.

\section{Pendidikan Ibu Balita}

Tabel 3 Frekuensi Pendidikan Ibu Balita di Posyandu V Desa Kletek, Mei 2018

\begin{tabular}{|c|c|c|}
\hline Pendidikan & $\mathrm{f}$ & $\%$ \\
\hline $\begin{array}{l}\text { SD/Tidak Tamat } \\
\text { SD }\end{array}$ & 21 & 23,3 \\
\hline SMP/Sederajat & 24 & 26,7 \\
\hline SMA/Sederajat & 35 & 38,9 \\
\hline Perguruan Tinggi & 10 & 11,1 \\
\hline Jumlah & 90 & 100 \\
\hline
\end{tabular}

\begin{tabular}{lcc}
\hline Gizi Buruk & 0 & 0 \\
Gizi Kurang & 19 & 21,1 \\
Gizi Baik & 66 & 73,3 \\
Gizi Lebih & 5 & 5,6 \\
Jumlah & 90 & 100 \\
\hline
\end{tabular}

Tabel 6 dapat dilihat bahwa mayoritas alita berstatus gizi baik sebanyak $66(73,3 \%)$ balita.

Status Ekonomi Dengan Status Gizi Balita

Tabel 7 Tabulasi Silang Status Ekonomi Dengan Status Gizi Balita di Posyandu V Desa Kletek, Mei 2018

Tabel 3 dapat dilihat bahwa mayoritas ibu balita berpendidikan SMA/Sederajattatus sebanyak 35 (38,9\%) ibu balita.

Pekerjaan Ibu Balita

Tabel 4 Frekuensi Pekerjaan Ibu Balitä Mngh Posyandu V Desa Kletek, Mei 2018

\begin{tabular}{lcc}
\hline \multicolumn{1}{c}{ Pekerjaan } & $\mathrm{f}$ & $\%$ \\
\hline PNS & 7 & 7,8 \\
Swasta & 14 & 15,5 \\
Buruh/Pegawai & 36 & 40 \\
Tidak Tetap & & \\
Tidak Bekerja/IRT & 33 & 36,7 \\
Jumlah & 90 & 100 \\
\hline
\end{tabular}

Tabel 4 dapat dilihat bahwa mayoritas ibu balita bekerja sebagai buruh/pegawai tidak tetap sebanyak 36 40\%) ibu balita.

\section{Status Ekonomi}

Tabel 5 Frekuensi Status Ekonomi Keluarga di Posyandu V Desa Kletek, Mei 2018

\begin{tabular}{lcc}
\hline \multicolumn{1}{c}{ Status Ekonomi } & $\mathrm{f}$ & $\mathrm{\%}$ \\
\hline Sangat Miskin & 1 & 1,1 \\
Miskin & 10 & 11,1 \\
Menengah & 33 & 36,7 \\
Kaya & 38 & 42,2 \\
Sangat Kaya & 8 & 8,9 \\
Jumlah & 90 & 100 \\
\hline
\end{tabular}

Tabel 5 dapat dilihat bahwa mayoritas status ekonomi keluarga balita berstatus sangat kaya sebanyak $38(42,2 \%)$ ibu balita.

\section{Status Gizi Balita}

Tabel 6 Frekuensi Status Gizi Balita di Posyandu V Desa Kletek, Mei 2018

$\begin{array}{lll}\text { Status Ekonomi } & \mathrm{f} & \%\end{array}$

\begin{tabular}{|c|c|c|c|c|c|c|c|c|c|}
\hline \multicolumn{8}{|c|}{ Status Gizi Balita } & \multicolumn{2}{|c|}{ Total } \\
\hline \multicolumn{2}{|c|}{ Buruk } & \multicolumn{2}{|c|}{ Kurang } & \multicolumn{2}{|c|}{ Baik } & \multicolumn{2}{|c|}{ Lebih } & \multirow{2}{*}{$\mathrm{f}$} & \multirow{2}{*}{$\%$} \\
\hline $\mathrm{f}$ & $\%$ & $\mathrm{f}$ & $\%$ & $\mathrm{f}$ & $\%$ & $\mathrm{f}$ & $\%$ & & \\
\hline 0 & 0 & 0 & 0 & 1 & 100 & 0 & 0 & 1 & 100 \\
\hline 0 & 0 & 2 & 20 & 8 & 80 & 0 & 0 & 10 & 100 \\
\hline 0 & 0 & 15 & 45,5 & 18 & 54,5 & 0 & 0 & 33 & 100 \\
\hline 0 & 0 & 2 & 5,3 & 34 & 89,5 & 2 & 5,3 & 38 & 100 \\
\hline 0 & 0 & 0 & 0 & 5 & 62,5 & 3 & 37,5 & 8 & 100 \\
\hline 0 & 0 & 19 & 21,1 & 66 & 73,3 & 5 & 5,6 & 90 & 100 \\
\hline
\end{tabular}

Tabel 7 dapat dilihat bahwa seluruh keluarga dengan status ekonomi miskin mempunyai $1(100 \%)$ balita dengan gizi baik, sebagian kecil keluarga dengan status ekonomi miskin mempunyai $2(20 \%)$ balita dengan status gizi kurang, mayoritas keluarga dengan status ekonomi miskin mempunyai 8 (80\%) balita dengan status gizi baik, hampir setengah keluarga dengan status ekonomi menengah mempunyai $15(45,5 \%)$ balita dengan status gizi kurang, mayoritas keluarga dengan status ekonomi menengah mempunyai $18(54,5 \%)$ balita dengan status gizi baik, sebagian kecil keluarga dengan status ekonomi kaya mempunyai 2 (5,3\%) balita dengan status gizi kurang, mayoritas keluarga dengan status ekonomi kaya mempunyai $34(89,5 \%)$ balita dengan status gizi baik, sebagian kecil keluarga dengan status ekonomi kaya mempunyai $2(5,3 \%)$ balita dengan status gizi lebih, mayoritas keluarga dengan status ekonomi sangat kaya mempunyai $5(62,5 \%)$ balita dengan status gizi baik, mayoritas seluruh keluarga dengan status ekonomi sangat kaya mempunyai 3 $(37,5 \%)$ balita dengan status gizi lebih.

Hasil uji statistik menggunakan uji korelasi rank spearman dimana nilai $\alpha=0,05$ pada variabel status ekonomi keluarga dan status gizi balita, didapatkan $\mathrm{p} \leq \alpha$ dengan $\mathrm{p}$ 
$=0,000$ ini menunjukkan bahwa Ho ditolak dan $\mathrm{H} 1$ diterima sehingga ada hubungan antara status ekonomi keluarga dengan status gizi balita di Posyandu V Desa Kletek Wilayah Kerja Puskesmas Taman Sidoarjo.

\section{PEMBAHASAN}

\section{Status Ekonomi}

Tabel 5 dapat dilihat bahwa dari $90 \mathrm{ibu}$ balita sebagian kecil memiliki keluarga dengan status ekonomi sangat miskin sebanyak $1 \quad(1,1 \%) \quad$ ibu, sebagian kecil memiliki keluarga dengan status ekonomi miskin sebanyak $10(11,1 \%)$ ibu, hampir setengah memiliki keluarga dengan status ekonomi menengah sebanyak $33(36,7 \%) \mathrm{ibu}$, hampir setengah memiliki keluarga dengan status ekonomi kaya sebanyak 38 (42,2\%) ibu dan sebagian kecil memiliki keluarga dengan status ekonomi sangat kaya sebanyak $8(8,9 \%)$ ibu.

Definisi status ekonomi menurut Kartono (2006) yang ditulis dalam bukunya adalah kedudukan seseorang didalam keluarga maupun masyarakat berdasarkan penghasilan yang didapat per bulan. Pemenuhan kebutuhan pokok didalam keluarga juga dapat dijadikan patokan jumlah pendapatan dalam status ekonomi.

Keadaan seseorang/keluarga di masyarakat menunjukkan finansial dan perlengkapan material yang dimiliki merupakan makna dari status ekonomi (Basrowi, 2010). Status ekonomi sangat dipengaruhi oleh tingkat pendapatan dan pengeluaran keluarga, apabila akses pangan ditingkat keluarga terganggu, terutama akibat kemiskinan, maka penyakit kurang gizi pasti akan muncul dikarenakan menurunnya daya beli pangan yang baik. Status ekonomi yang rendah akan mengakibatkan lemahnya daya beli sehingga membuat tidak mungkinnya suatu keluarga dalam mengatasi kebiasaan makan dengan cara-cara tertentu secara efektif pada anak mereka. Sedangkan status ekonomi yang terjadi peningkatan akan mempengaruhi perbaikan kesehatan serta keadaan gizi anak.

Data diatas menunjukkan bahwa hampir setengah $(42,2 \%)$ ibu balita di Posyandu V Desa Kletek Wilayah Kerja Puskesmas Taman Sidoarjo memiliki keluarga dengan status ekonomi kaya, hal ini dipengaruhi oleh tingkat pendidikan ibu balita yang hampir setengah $(38,9 \%)$ berpendidikan SMA dan pekerjaan ibu balita yang hampir setengah (40\%) bekerja sebagai buruh/ pegawai tidak tetap.

Keluarga ibu balita di Posyandu V tergolong kaya dipengaruhi oleh pendidikan ibu yang tinggi juga hal ini sesuai dengan teori FKM UI (2007) yang menyatakan bahwa dengan meningkatnya pendidikan kemungkinan akan meningkatkan pendapatan sehingga ibu bisa menggunakan pendidikan, pengetahuan dan pengalaman tersebut untuk mendapat pekerjaan dan penghasilan yang cukup agar bisa memenuhi kebutuhan sandang dan pangan bagi keluarga khususnya bagi balitanya dan bisa berkesempatan untuk hidup dalam lingkungan yang baik dan sehat.

Oleh sebab itu, ibu yang bekerja diluar rumah bisa memanfaatkan penghasilan dan pengetahuannya untuk memenuhi kebutuhan gizi keluarganya serta dapat mengatur waktu dalam mengasuh anaknya. Pengetahuan dan sikap ibu tentang upaya peningkatan status gizi yang baik sangat menunjang ketika ibu bekerja diluar rumah maupun dalam rumah, dalam hal ini ibu dapat mengatur waktu ketika memberi makanan, merawat, menjaga kesehatan dan kebersihan, memberikan kasih sayang serta dapat memantau pertumbuhan dan perkembangan anak-anaknya.

\section{Status Gizi Balita}

Tabel 6 dapat dilihat bahwa dari $90 \mathrm{ibu}$ balita tidak satupun memiliki balita dengan status gizi buruk, sebagian kecil memiliki balita dengan status gizi buruk sebanyak 19 $(21,1 \%)$ ibu, sebagian besar memiliki balita dengan status gizi baik sebanyak $66(73,3 \%)$ ibu dan sebagian kecil memiliki balita dengan status gizi lebih sebanyak $5(5,6 \%)$ ibu.

Menurut Sediaoetama (2010) status gizi merupakan hasil akhir suatu keadaan tubuh yang berasal dari keseimbangan antara zat gizi yang masuk ke dalam dan keluar tubuh.

Konsumsi lemak yang tinggi dan makanan dari gula murni berkaitan dengan status gizi lebih apabila dikonsumsi melebihi dari jumlah yang dibutuhkan oleh tubuh. Status gizi lebih (obesitas) pada anak akan berdampak pada tingginya jumlah kejadian penyakit infeksi apabila tidak segera diatasi dan akan berlanjut sampai remaja dan dewasa. Cara untuk menanggulangi hal tersebut adalah dengan menyeimbangkan masukan dan keluaran energi melalui 
perubahan pada pola makan yakni dengan mengurangi porsi makan.

Kesesuaian antara jumlah asupan yang masuk dengan kebutuhan gizi seorang anak akan membuat anak tersebut masuk dalam kategori anak dengan status gizi baik. Pertumbuhan fisik dan otak, kemampuan dalam bekerja, dan kesehatan secara umum dapat dicapai apabila tubuh memperoleh zatzat gizi yang cukup untuk digunakan secara efisien sehingga tubuh dalam kondisi status gizi baik.

Kekurangan asupan energi dan protein dalam kurun waktu tertentu menjadi penyebab terjadinya gangguan kesehatan pada status gizi kurang. Kurangnya asupan makanan dan terjadinya infeksi merupakan dua hal yang saling mempengaruhi dan ditimbulkan akibat gizi kurang. Kurangnya sanitasi dan kebersihan, pelayanan kesehatan dasar yang kurang/tidak memadai, pola asuh anak yang tidak memadai, serta rendahnya ketahanan pangan dalam suatu rumah tangga menyebabkan terjadinya penyakit infeksi. Gizi buruk dapat terjadi apabila kondisi gizi kurang berlangsung dalam waktu yang lama sehingga berakibat semakin berat kekurangannya. Status gizi buruk akan mempengaruhi banyak organ dan sistemnya sehingga akan merusak sistem pertahanan tubuh. Selanjutnya, dampak yang dapat terjadi adalah gangguan pertumbuhan dan perkembangan dari mental anak serta adanya penurunan dari fungsi otak yang juga berpengaruh terhadap kemampuan dalam belajar, bereaksi terhadap rangsangan dari lingkungan, serta perubahan kepribadian pada anak.

Berdasarkan hasil penelitian, sebagian besar ibu balita di Posyandu V Desa Kletek Wilayah Kerja Puskesmas Taman Sidoarjo memiliki balita dengan status gizi baik $(73,3 \%)$, hal ini menujukkan bahwa orang tua sudah paham tentang pentingnya gizi seimbang dan sudah mampu untuk memenuhi kebutuhan gizi anak-anaknya.

Tingkat pendidikan dalam keluarga khususnya pendidikan ibu dapat menjadi faktor yang mempengaruhi status gizi anak dalam keluarga. Menurut Soekirman (2000), pengetahuan ibu tentang gizi akan semakin bertambah sesuai dengan tingginya status pendidikan ibu. Mudah atau tidaknya seseorang dalam menyerap dan mempunyai pemahaman pengetahuan tentang gizi dan kesehatan juga ditentukan dari tingkat pendidikan. Status gizi balita di Posyandu V tergolong baik dan pendidikan ibu balita juga tinggi hal ini sesuai dengan teori Soekirman (2000) tersebut. Tingkat pendidikan ibu sangat berpengaruh dalam hal ini ibu yang memiliki pendidikan tinggi akan lebih banyak tahu tentang kesehatan dan memiliki status kesehatan yang lebih baik. Oleh karena itu, dalam meningkatkan upaya perbaikan gizi diharapkan orang tua dapat lebih memberikan nutrisi yang baik dan seimbang agar memenuhi kebutuhan gizi serta menerapkan pola hidup sehat pada anaknya. Pemenuhan kebutuhan gizi pada anak diharapkan dapat meningkatkan kualitas hidup serta mengurangi angka kesakitan dan kematian, serta anak dapat tumbuh dan berkembang sesuai dengan usia pertumbuhan.

\section{Hubungan Status Ekonomi Keluarga dengan Status Gizi Balita}

Tabel 7 dapat dilihat bahwa seluruh keluarga dengan status ekonomi miskin mempunyai $1(100 \%)$ balita dengan gizi baik, sebagian kecil keluarga dengan status ekonomi miskin mempunyai $2(20 \%)$ balita dengan status gizi kurang, mayoritas keluarga dengan status ekonomi miskin mempunyai 8 $(80 \%)$ balita dengan status gizi baik, hampir setengah keluarga dengan status ekonomi menengah mempunyai $15(45,5 \%)$ balita dengan status gizi kurang, mayoritas keluarga dengan status ekonomi menengah mempunyai $18(54,5 \%)$ balita dengan status gizi baik, sebagian kecil keluarga dengan status ekonomi kaya mempunyai $2(5,3 \%)$ balita dengan status gizi kurang, mayoritas keluarga dengan status ekonomi kaya mempunyai $34(89,5 \%)$ balita dengan status gizi baik, sebagian kecil keluarga dengan status ekonomi kaya mempunyai $2(5,3 \%)$ balita dengan status gizi lebih, mayoritas keluarga dengan status ekonomi sangat kaya mempunyai $5(62,5 \%)$ balita dengan status gizi baik, mayoritas seluruh keluarga dengan status ekonomi sangat kaya mempunyai 3 $(37,5 \%)$ balita dengan status gizi lebih.

Kedudukan seseorang atau keluarga di suatu masyarakat berdasarkan pendapatan yang diperoleh setiap bulan disebut dengan status ekonomi. Menurut Kartono (2006) status ekonomi seseorang dapat dilihat berdasarkan pendapatan yang diperoleh per 
bulan yang disesuaikan dengan besarnya harga barang pokok saat itu.

Berdasarkan hasil penelitian yang dilakukan oleh Johanes (2011) menyatakan bahwa tingkat pendapatan seseorang menentukan pola makan yang dikonsumsi, serta semakin tingginya pendapatan seseorang tersebut maka semakin bertambah pula pengeluaran untuk biaya belanja. Hal ini menyangkut pemenuhan kebutuhan dalam keluarga terutama pemenuhan kebutuhan akan makanan yang memiliki nilai gizi dengan jumlah yang cukup dengan demikian faktor yang paling menentukan kualitas dan kuantitas dari makanan adalah pendapat keluarga.

Faktor yang menentukan jumlah makanan yang tersedia dalam suatu keluarga ditentukan oleh status ekonomi keluarga tersebut sehingga status ekonomi tersebut juga turut menentukan status gizi keluarga tersebut. Keluarga dengan status ekonomi tinggi akan menunjukkan gaya hidup mewah mereka seperti mampu membeli dan memenuhi semua kebutuhan yang dibutuhkan, dibandingkan dengan keluarga dengan status ekonomi rendah.

Besar kecilnya pendapatan dan pengeluaran suatu keluarga mempengaruhi kemampuan keluarga untuk membeli dan memenuhi kebutuhan bahan makanan. Terdapatnya hubungan antara status ekonomi dan keadaan status gizi anak, dikarenakan tingkat ekonomi merupakan faktor yang sangat menentukan dalam kuantitas serta kualitas pada makanan yang disediakan. Perbandingan antara status ekonomi yang meningkat dengan status ekonomi yang rendah berpengaruh terhadap perbaikan dan keadaan gizi keluarga dalam hal kuat dan lemahnya daya beli keluarga tersebut untuk mengatasi kebiasaan makan dengan cara-cara tertentu yang dilakukan secara efektif terutama untuk anak mereka.

Hasil uji statistik menggunakan uji korelasi rank spearman menunjukkan adanya hubungan sedang antara status ekonomi keluarga dengan status gizi balita dengan $p=$ 0,000 . Hasil penelitian menunjukan dari 90 ibu balita hampir seluruhnya (89,5\%) memiliki balita dengan status gizi baik dan memiliki keluarga dengan status ekonomi kaya hal ini sesuai dengan pernyataan Erma (2013) yang menunjukan bahwa tingkat status ekonomi yang tinggi akan meningkatkan konsumsi pada jenis makanan dengan nilai gizi yang baik dibandingkan dengan yang memiliki tingkat ekonomi rendah.

Tingkat ekonomi yang tinggi pada suatu keluarga membuat keluarga sanggup membelanjakan sebagian besar dari pendapatan mereka untuk akses pangan serta memenuhi kebutuhan gizi dari keluarganya, sedangkan tingkat ekonomi yang sedang pada suatu keluarga membuat keluarga terbatas dalam pemenuhan akses pangan serta pemenuhan gizi dari keluarganya.

Oleh karena itu, untuk orang tua yang mempunyai status ekonomi rendah diharapkan juga memberikan makanan yang bergizi bagi anaknya. Makanan yang bergizi tidak harus diperoleh dari makanan yang mahal. Makanan yang bergizi juga bisa di dapat dari bahan makanan yang murah, tapi mengandung gizi yang cukup.

\section{SIMPULAN}

Ada hubungan antara status ekonomi keluarga dengan status gizi balita di Posyandu V Desa Kletek Wilayah Kerja Puskesmas Taman, Sidoarjo.

\section{SARAN}

Diharapkan petugas kesehatan khususnya bidan setempat diharapkan lebih sering (6 bulan sekali) melakukan penyuluhan tentang gizi seimbang pada balita dan memberikan contoh menu seimbang dari bahan makanan yang murah, tapi mengandung gizi yang cukup.

\section{Daftar Pustaka}

Arikunto, S., 2007. Prosedur Penelitian Suatu Pendekatan Praktik. Jakarta : Rineka Cipta.

Bobak, Lowdermilk, dan Jensen., 2005. Buku Ajar Keperawatan Maternitas. Jakarta : EGC.

Depkes Jatim., 2013. Profil kesehatan Jawa Timur Tahun 2008. Jakarta : Depkes Jatim

2014. Profil kesehatan Jawa Timur Tahun 2009. Jakarta : Depkes Jatim

2015. Profil kesehatan Indonesia Tahun 2010. Jakarta : Depkes Jatim

Depkes RI., 2010a. Pedoman Pelayanan Antenatal Terpadu. Jakarta : Depkes RI 
2010b. Profil kesehatan Indonesia Tahun 2010. Jakarta : Depkes RI

Notoatmodjo, S., 2007. Pendidikan dan Perilaku Kesehatan. Jakarta : Rineka Cipta , 2010a. Ilmu Perilaku, Teori dan aplikasi. Jakarta : Rineka Cipta 2010b. Metodologi Penelitian Kesehatan. Jakarta : Rineka Cipta

Nursalam dan Pariani, S., 2001. Pendekatan Praktis Metodologi Riset Keperawatan. Jakarta : Sagung Setio
Nursalam, 2008. Konsep dan Penerapan Metodologi Penelitian Ilmu Keperawatan. Jakarta: Salemba Medika

Saifuddin, A.B, et al., 2007. Buku Acuan Nasional. Pelayanan Kesehatan Maternal dan Neonatal. Jakarta: Yayasan Bina Pustaka Sarwono Prawirohadjo

Sulistyawati, A., 2009. Asuhan Kebidanan Pada Masa Kehamilan. Jakarta : Salemba Medika 